Елена Андрущенко

ORCID: 0000-0002-8260-4961

Институт мировой литературы им. А.М. Горького

Российской академии наук

Москва, Россия

\title{
ПРОПОВЕДНИЧЕСКОЕ И ИСПОВЕДАЛЬНОЕ В ПУБЛИЦИСТИКЕ Д. МЕРЕЖКОВСКОГО 1905-1908 ГГ.
}

\author{
https://doi.org/10.34739/clit.2020.14.10
}

\section{THE PREDICANT AND THE CONFESSIONAL IN D. MEREZHKOVSKY'S SOCIAL WRITINGS OF 1905-1908}

The article attempts to discover elements of the predicant and confessional dimensions in D. Merezhkovsky's social publications of 1905-1908. The predicant intention surfaces when the author strives to establish the idea of the Third Testament or the Kingdom of the Holy Spirit, finding its implementation in tendentious perception of biblical verses, interpretation and resolution of contradictions, as well as the construction of an optimistic perspective. His open letter to N. Berdiaev clearly exhibits a confessional streak, combining elements of a confessional letter, an intellectual autobiography, as well as a socially oriented sermon and article.

Keywords: Merezhkovsky, predicant and confessional dimensions, social publications, prophetic sermon, missionary message, confessional letter

Творчество Д. Мережковского изучается давно и плодотворно. Однако в научных исследованиях вопрос о проповедническом и исповедальном в произведениях писателя специально не рассматривался. Современники обращали внимание на его стремление быть, по выражению Н. Бердяева, «пророком новой веры»1, а по словам Вяч. Иванова, - «пророком, восхотевшим священствовать, и изволению своего пророческого священства

\footnotetext{
${ }^{1}$ Н. Бердяев, Духовный кризис интеллигенции, Москва 1998, с. 30.
} 
подчиняющий, в конечном выводе, царство»². В. Базаров в своей неприязненной статье назвал Д. Мережковского несостоявшимся «пророком религиозного возрождения русской интеллигенции» 3 . Не претендуя на полноту осмысления, затронем лишь некоторые аспекты этой темы, представляющие значительный интерес для истолкования поэтики писателя.

Литературная проповедь и исповедь имеют в русской литературе богатую традицию, но было бы поверхностно причислять произведения Д. Мережковского к ней. Думается, можно говорить только об установке на проповедничество или исповедальность, отчетливо проявившихся в его публицистике периода первой русской революции, когда идеи религиозного и социального преобразования требовали от писателя специфического инструментария, направленного на достижение идеологических целей. В этом смысле показательным является сборник статей Д. Мережковского Не мир, но меч, который вышел в свет в 1908 г. и включал статьи, публиковавшиеся в периодической печати в течение нескольких лет. В названии сборника использована реминисценция из Мф. (10:34): «не мир пришел Я принести, но меч». Подзаголовок к названию сборника гласит: «К будущей критике христианства». Семантика заглавия и подзаголовка сигнализирует о том, что статьи, составившие сборник, связаны с религиозно-философской тематикой, опрокинутой, как это практиковал Д. Мережковский, в актуальные события современности.

В связи с концепцией писателя, направленной на истолкование идеи Церкви Третьего Завета или Царства Духа Святого, пафос статей связан с проповедническим дискурсом, организующим текст и имеющим вид непрямого поучения, риторического призыва, специфического истолкования библейского текста. Проповедническая установка очевидна, прежде всего, в статье Д. Мережковского Меч. Ее прообразом может считаться, скорее всего, профития, которая адресована неизвестному автору аудитории. Как проповедник «нового религиозного сознания», Д. Мережковский вносит в свой текст и дидактические элементы, что в сочетании с элементами профитии превращает его в своего рода миссионерское послание. Учитывая появление статьи в сборнике публицистических статей, можно говорить о том, что в ней заключена «память» жанра (М. Бахтин) публицистической проповеди.

\footnotetext{
2 Вяч. Иванов, Из области современных настроений. I. Апокалиптики и общественность, „Весы” 1905, № 6, с. 37.

3 В. Базаров, Христиане Третьего завета и строители башни Вавилонской, [в:] Литературный распад, кн. 2, Санкт Петербург 1909, с. 5.
} 
Свою статью Д. Мережковский начинает с риторического вопроса: «Есть Бог или нет?», связанного с уверенностью в том, что человечество не только утратило веру, но и пассивно относится к религии:

Если что-либо в религиозных переживаниях потеряно окончательно и как будто невозвратно, то это именно ощущение религиозного действия. Пока говоришь о религии, как об идеале, все соглашаются или, по крайней мере, никто не спорит - кажется, впрочем, потому, что всем наплевать; но только что пытаешься связать религию с реальной действительностью, оказываешься или в дураках, или в подлецах, ибо за память современного человечества единственная религиозно-общественная реальность - глупость обманутых, подлость обманщиков 4 .

Композиция статьи подчинена задаче привлечь внимание читателя к проблеме действенности религии. В статье двенадцать главок, в каждой из них освещена своя тема: сопоставление религии с наукой, искусством, родом, общественностью; уход из христианства в буддийское неделание и действенный анархизм; антиномия любви и смерти; проблема воскресения и ее противоречие разуму; конец христианства как начало новой религии; истолкование смысла религии Третьего Завета; христианство как борьба духа с плотью, победа аскетизма; проблема пола в христианстве; христианство и общественность; разрушение идеи церкви и, наконец, осуществление подлинной церкви. После парадоксального зачина или вступления Д. Мережковский переходит к информативно-повествовательной части, в центр которой выдвигается сюжет о воскресении Христа, веру в которое или неверие автор объясняет ростом научных знаний, скепсиса и давлением государства: «Безнадежная противообщественность христианства, кощунственное смешение церкви с государством, тела Христова с телом зверя, есть главная причина того, что современное человечество отшатнулось от христианства»5. Развивая эту мысль, автор и оправдывает негативное отношение человечества к религии, и предлагает пути к устранению обнаруженного им противоречия.

В конце статьи Д. Мережковский использует явный проповеднический прием, когда стройная и интеллектуально напряженная проповедь «нового религиозного сознания» завершается оптимистическим и утверждающим финалом:

4 Д.С. Мережковский, Не мир, но меч. К будущей критике христианства, Санкт-Петербург 1903, с. 3.

5 Ibidem, c. 33. 
Не приходит Царствие Божие приметным образом и не скажут о нем: вот оно там или вот - здесь. Се Царствие Божие внутри вас есть. Но нет ничего тайного, что не сделалось бы явным, и ничего внутреннего, что не сделалось бы внешним. Прихождение Царства Божиего невидимо; но пришествие его не может не быть видимым: ибо, как молния исходит на востоке и видна бывает даже до запада, так будет пришествие Сына Человеческого. Царство Божие и есть эта молния, рассекающая небо и землю, соединяющая небо и землю. Христианская церковь, вернее - идея о церкви, потому что самой церкви не было в христианстве - всегда или уходила от мира, или, входя в него, теряла остроту свою, притупляла свой меч. Истинная Церковь войдет в мир, врежется в исторически-реальное человечество, как в живое тело врезается меч. Не думайте, что Я пришел принести мир на землю; не мир пришел Я принести, но меч. Церковь грядущего Господа и есть этот меч 6 .

Утверждение идеи Церкви Третьего Завета потребовало от Д. Мережковского использования некоторых приемов: тенденциозного истолкования библейских стихов, выявления, интерпретации и разрешения противоречий, обнажения оптимистической перспективы. Ревизия исторического христианства, которой, по сути, насыщен этот текст, ведется, однако, традиционным проповедническим путем.

Сборник Не мир, но меч представляет собой собрание публицистических статей. В каждой из них своя доминанта: политическая - в статье Революция и религия и в предисловии к сборнику Царь и революция, притчевая - в статье Последний святой. Таких примеров в публицистике Д. Мережковского 1905-1908 гг. немало: он активно печатался в «Русской мысли», «Образовании», «Весах» и «Речи», что обусловливало выбор той или иной стратегии, направленной на усиление аргументации, упрочение позиции. В некотором противоречии с ними находится статья О новом религиозном действии (Открытое писъмо Н.А. Бердяеву) (1905), вышедшая в свет после нашумевших статей Грядущий Хам и Теперь или никогда и явно выбивающаяся из общего пропагандистско-проповеднического единства: в ней исповедальное начало преобладает над проповедническим.

Как известно, в русской литературе создано немало писательских исповедей. Л. Луцевич в статье Документальность, эго-документ, русская писательская исповедь (2018) предложила убедительную типологию, в которой выделила

\footnotetext{
${ }^{6}$ Ibidem, c. 39.
} 
три разновидности исповедей: исповеди, ориентированные на исповедание христианского вероучения (религиозные), основу которых составляет сюжет обращения; исповеди социально-политического дискурса, в основе сюжета - отход / отказ автора от прежних политических убеждений; исповеди позитивистского толка (антропологические), в их основе индуктивное - естественнонаучное самопознание автора7.

Эта типология позволяет говорить о том, что в адресованном Н. Бердяеву послании Д. Мережковский использует инструментарий, характерный одновременно и для исповеди религиозной, и для исповеди социально-политического дискурса, ведь в нем одновременно пересматриваются и религиозные, и общественнополитические взгляды автора.

Его статья была опубликована в 1905 г. в журнале «Вопросы жизни» 8 в ответ на статью Н. Бердяева $O$ новом религиозном сознании 9 . Исповедальность, на первый взгляд, обеспечивается формой письма, адресованного Н. Бердяеву. Довольно часто именно в письмах автор доверительно сообщает о своих переживаниях, мыслях, пережитых им событиях, и было бы неверно оставить без внимания эту жанровую матрицу. Но, с другой стороны, этот текст был опубликован в периодической печати, что заранее предполагает не одного, а множество читателей. Сочетание проповеднического и исповедального начал оформляет текст в пронзительное послание. У всех, кто хорошо знает литературную критику и публицистику писателя, а также его открытые письма в газеты, это письмо не может не вызвать удивления, настолько его интонация, проникновенность и искренность отличаются от всего, что Д. Мережковский обычно представлял читателю.

Так, оно начинается с признания:

«Полюби не меня, а мое» - эта незаглушимая потребность всякого писателя, у которого есть что-нибудь, чем он дорожит больше, нежели самим собою, - отнюдь не потребность внешнего литературного успеха, а внутренней живой связи с читателем в любви к Единому. До сих пор у меня этой связи почти не было. В России меня не любили и бранили; за границей меня любили и хвалили; но и здесь и там одинаково не понимали моего.

\footnotetext{
7 Л.Ф. Луцевич, Документальность, эго-документ, русская писательская исповедь, [в:] Документ и документальное в славянских культурах: между подлинньм и мнимъмм, отв. ред. Н.М. Куренная, Москва 2018, с. 52.

8 Д.С. Мережковский, $O$ новом религиозном действии (Открытое письмо Н.А. Бердяеву), „Вопросы жизни” 1905, кн. 10-11, с. 358-376.

9 Н.А. Бердяев, О новом религиозном сознании, „Вопросы жизни” 1905, кн. 9, с. 147-188.
} 
Я испытывал минуты такого одиночества, что становилось жутко; иногда казалось, что или я нем, или все глухи; иногда хотелось воскликнуть с тем последним отчаянием, которым искушал меня мой вечный искуситель, В.В. Розанов, в статье своей «Среди иноязычных», с таким нежным и предательским лукавством: никто ничего не понимает, никто ничего никогда не поймет. Если я не впал в отчаяние, если сохранил надежду, то только благодаря тому, что, будучи один в литературе, в жизни я не был один... ${ }^{10}$

В этом фрагменте автор прибегает к формулировке своего кредо и к обнажению чувств, которые, по его признанию, он испытывал в процессе творчества. Здесь ощутима двойственная природа исповедальности: выражение разлада с самим собой и с обществом, неуверенность в своих силах и способностях и, вместе с тем, стремление к самоосуществлению, к утверждению своей правоты ${ }^{11}$. И более того, Д. Мережковский открывает свои потаенные ожидания, оправданные статьей Н. Бердяева:

И надежда не постыдила меня. Вот уже в литературе я не один. Вы со мною? Или, может быть, я с Вами? Не все ли равно? Главное, мы вместе. Вы полюбили не меня, а мое. Это великая радость. Ибо для меня литература - вторая жизнь, не менее глубокая, чем первая ${ }^{12}$.

Итак, исповедальное начало, ощутимое в этом письме, является способом выражения потребности в самопознании и, вместе с тем, в обретении единомышленника. Д. Мережковский объясняет, в чем он ощутил поддержку: в освещении светом «философского сознания» сложных для него религиозных вопросов; напомним, что Н. Бердяев упрекал писателя в том, что он испытывал соблазн идеей православного государства:

Вы показали, что поставленная мною с недостаточною твердостью метафизическая проблема о «духе» и «плоти» разрешается не в метафизическом, а в мистическом порядке, в откровении триединства Божественных ипостасей, в соединении двух ликов, Отчего и Сыновнего, в третьем лике Духа; Вы показали, что моя борьба с монашеским аскетизмом и спиритуализмом исторического

10 Д.С. Мережковский, $О$ новом религиозном действии (Открытое письмо Н.А. Бердяеву), [в:] Мережковский Д.С., Полн. собр. соч.: в 24 m. T. XIV, Москва 1914, c. $166-167$.

${ }^{11}$ См. также: Л. Луцевич, «Исповедъ» Константина Леонтьева: текст и контекст, [в:] Текст и традиции: альманах, 4, Санкт-Петербург 2016, с. 41-58. Л. Луцевич, Три лика Жан-Жака Руссо (Мережковский, Философов, Розанов), „Соловьевские исследования" 2019, № 1 (61), с. 127-140.

12 Д.С. Мережковский, О новом религиозном действии..., оp. cit., с. 167. 
христианства слишком внешняя, поверхностная, слишком «позитивная» $(. . .)^{13}$

Здесь очевидно, что исповедальное потесняется потребностью в утверждении, даже навязывании своего понимания, осуществляемом проповедническим инструментарием. Д. Мережковский прибегает к такой форме высказывания, в которой уже не сомнения определяют его позицию, а уверенность, представленная как своего рода программа, к исполнению которой он призывает собеседника:

Надо преодолеть в христианстве историческом не метафизикой метафизику, не мыслью мысль, а опытом опыт, откровением откровение; надо не говорить о том, что два суть едино, а явить едино в двух, сделать, чтобы два были едино. И пока это не явлено, не сделано, не следует отрекаться от метафизики для мистики ${ }^{14}$.

Комбинация инструментария двух типов создает такой вид высказывания, в котором одновременно происходит обнажение чувств, переживаний, представленных в форме самопризнаний, и утверждения своей мысли, позиции, основанных на интерпретации библейского текста:

Кровавого пота стоило Сильнейшему из людей слово, соединяющее последнюю любовь с последней свободой: Не Моя, а Твоя да будет воля. Чего же оно будет стоить нам? Заповедь новую даю вам, да любите друг друга. Если это повторение того, что уже сказано в Ветхом Завете: «люби ближнего твоего, как самого себя», - то это была бы заповедь не новая. Любовь, которую заповедал Христос, потому и есть «новая», что она не только любовь, но и свобода, не только путь личного, но и общественного, всечеловеческого, вселенского спасения. Эта любовь - бесконечная свобода и, вместе с тем, бесконечная власть, о которой сказано: «Мне принадлежит всякая власть на земле и на небе». Если жив Христос, - а Он воистину жив, потому что воистину воскрес, - то жив наш царь и не может быть иного царя, иной власти ни на небе, ни на земле, кроме Христа ${ }^{15}$.

Автор свободно комбинирует библейские реминисценции и искаженные библейские цитаты, которые в таком сочетании рождают новый смысл, ведь в исходном тексте они находятся в ином окружении: «кровавого пота» - реминисценцию из Лк. (22:44), «Не Моя, а Твоя да будет воля» - неточно из Лк. (22:42), «Заповедь

13 Ibidem, c. 168.

14 Ibidem, c. 168-169.

15 Ibidem, c. 173-174. 
новую даю вам, да любите друг друга» - неточно из Ин. (13:34), «люби ближнего твоего, как самого себя» - из Мф. (22: 39), «Мне принадлежит всякая власть на земле и на небе» - неточно из Мф. (28:18) и часть Пасхального приветствия «воистину воскрес». В конце письма автор прибегает к приему, в котором личное признание обретает полноту публицистического высказывания, каковым, в сущности, и было задумано. Д. Мережковский, наконец, использует форму говорения от «мы», т.е. переключается из исповедально-проповеднического регистра в пропагандистский, позволяющий ему утверждать собственную точку зрения как общую, коллективную. Он объявляет, что у него и его собеседника общий путь, на который следует вступить, чтобы «новое религиозное сознание» было соединено с «новым религиозным действием». Эта тонкая игра слов из заглавий обеих статей становится убедительным публицистическим приемом и оформляет финал статьи, отбрасывая отсвет на весь ее текст.

В открытом письме к Н. Бердяеву Д. Мережковский прибегает к сочетанию инструментария двух типов: проповеднического, довольно характерного его статьям, посвященным утверждению идеи Церкви Третьего Завета или Духа Святого, и исповедального, обычно не используемого им в публичной сфере. Последнее стало возможным благодаря форме письма, в котором может выражаться особое состояние, предполагающее искреннее осмысление своего чувства, мысли в стремлении осознать их, признаться в противоречиях, слабости, недальновидности. Комбинация этого инструментария обеспечила особый характер текста, в котором сочетаются элементы различных жанров: публицистической проповеди, исповедального письма, интеллектуальной автобиографии и публицистической статьи.

В собрании своих сочинений в 24 томах Д. Мережковский поместил этот текст в характерное окружение: в XIV томе печатались статьи Грядущий Хам, Желтолицые позитивисты, Чехов и Горький, Теперь или никогда, Страшный суд над русской интеллигенцией, Св. София и Пророк русской революции (К юбилею Достоевского). Состав тома подтверждает, что автор мыслил открытое письмо Н. Бердяеву как публицистическое выступление, в котором универсальный способ выражения состояния исповедальности направлен на решение и внутренней психологической проблемы автора, и задачи общественно важной, во всяком случае, важной для группы людей, от имени которых он выступает.

Итак, в публицистике Д. Мережковского 1905-1908 гг. очевидна преобладающая установка на проповедничество, связанная с необходимостью утверждения идеи Третьего Завета или Царства 
Духа Святого. Время острых социальных противоречий требовало от него этого специфического инструментария, позволяющего достичь определенных религиозно-философских целей. Статья Н. Бердяева затрагивала наиболее существенные аспекты концепции Д. Мережковского и во многом дискредитировала ее. Полемизировать с ним в той области, где Н. Бердяев был гораздо более убедителен, Д. Мережковский не мог, а форма искренней дружеской исповеди позволяла ему избежать открытого противостояния. В полемике с оппонентом, тонко чувствующим сомнительные аспекты концепции «нового религиозного сознания», он прибегает к установке на исповедальность, позволившей ему обойти обсуждение по существу, но признать ошибочность пережитых им соблазнов и представить оппонента единомышленником и сторонником.

\section{Литература}

Базаров В., Христиане Третьего завета и строители башни Вавилонской, [в:] Литературный распад, кн. 2, Санкт-Петербург 1909, c. 5-38.

Бердяев Н., Духовный кризис интеллигенции, Москва 1998.

Бердяев Н.А., О новом религиозном сознании, „Вопросы жизни” 1905, кн. 9, с. 147-188.

Иванов В.., Из области современных настроений. I. Апокалиптики и общественность, „Весы” 1905, № 6, с. 37-38.

Луцевич Л., «Исповедь» Константина Леонтьева: текст и контекст,

[в:] Текст и традиции: альманах, 4, Санкт-Петербург 2016, с. 41$-58$.

Луцевич Л., Три лика Жан-Жака Руссо (Мережковский, Философов, Розанов), „Соловьевские исследования” 2019, № 1 (61), с. 127-140. Луцевич Л.Ф., Документальность, эго-документ, русская писательская исповедь, [в:] Документ и документальное в славянских культурах: между подлинным и мнимым, отв. ред. Н.М. Куренная, Москва 2018, с. 41-62.

Мережковский Д.С., Не мир, но меч. К будущей критике христианства, Санкт-Петербург 1903.

Мережковский Д.С., О новом религиозном действии (Открытое письмо Н.А. Бердяеву), „Вопросы жизни” 1905, кн. 10-11, с. 358-376.

Мережковский Д.С., О новом религиозном действии (Открытое письмо Н.А. Бердяеву), [в:] Мережковский Д.С., Полн. собр. соч.: в $24 \mathrm{~m}$. T. XIV, Москва 1914, с. 166-187. 


\section{References}

Bazarov V., Hristiane Tret'ego zaveta i stroiteli bašni Vavilonskoj, [v:] Literaturnyj raspad, kn. 2, Sankt-Peterburg 1909, s. 5-38.

Berdâev N., Duhounyj krizis intelligencii, Moskva 1998.

Berdâev N.A., O novom religioznom soznanï, „Voprosy žizni” 1905, kn. 9, S. $147-188$.

Ivanov Vâč, Iz oblasti sovremennyh nastroenij. I. Apokaliptiki i obŝestvennost', ,Vesy” 1905, № 6, s. 37-38.

Lucevič L., «Ispoved'» Konstantina Leont'eva: tekst ikontekst, [v:] Tekst i tradicii: al'manah, 4, Sankt-Peterburg 2016, s. 41-58.

Lucevič L., Tri lika Žan-Žaka Russo (Merežkovskij, Filosofov, Rozanov), „Solov'evskie issledovaniâ" 2019, № 1 (61), s. 127-140.

Lucevič L.F., Dokumental'nost', ègo-dokument, russkaâ pisatel'skaâ ispoved', [v:] Dokument i dokumental'noe $v$ slavânskih kul'turah: meždu podlinnym i mnimym, otv. red. N.M. Kurennaâ, 2018, s. 41-62.

Merežkovskij D.S., Ne mir, no meč. K buduŝej kritikehristianstva, SanktPeterburg 1903.

Merežkovskij D.S., O novom religioznom dejstvii (Otkrytoe pis'mo N.A. Berdâevu), „Voprosy žizni” 1905, kn. 10-11, s. 358-376.

Merežkovskij D.S., O novom religioznom dejstvii (Otkrytoe pis'mo N.A. Berdâevu), [v:] Merežkovskij D.S., Poln. sobr. soč.: $v 24$ t., T. XIV, Moskva 1914, s. 166-187. 